Rural Sociology 82(1), 2017, pp. 101-128

DOI: 10.1111 /ruso.12111

Copyright (C) 2016, by the Rural Sociological Society

\title{
Conservation Management of EU Priority Habitats after Collapse of Traditional Pastoralism: Navigating Socioecological Transitions in Mountain Rangeland
}

\author{
João Pradinho Honrado \\ Faculdade de Ciências \\ Universidade do Porto \\ CIBIO-InBIO, Centro de Investigação em Biodiversidade e Recursos Genéticos
}

Universidade do Porto

Angela Lomba

CIBIO-InBIO, Centro de Investigação em Biodiversidade e Recursos Genéticos

Universidade do Porto

\author{
Paulo Alves \\ CIBIO-InBIO, Centro de Investigação em Biodiversidade e Recursos Genéticos \\ Universidade do Porto
}

\section{Carlos Aguiar \\ CIMO, Mountain Research Center \\ Polytechnic Institute of Bragança}

\section{Tiago Monteiro-Henriques}

CEF, Centro de Estudos Florestais, Instituto Superior de Agronomia

Universidade de Lisboa

\author{
Yvonne Cerqueira \\ CIBIO-InBIO, Centro de Investigação em Biodiversidade e Recursos Genéticos \\ Universidade do Porto
}

\section{Paulo Monteiro}

QUERCUS, Associação Nacional de Conservação da Natureza

\author{
Francisco Barreto Caldas \\ Faculdade de Ciências \\ Universidade do Porto \\ CIBIO-InBIO, Centro de Investigação em Biodiversidade e Recursos Genéticos \\ Universidade do Porto
}

AbSTRACT Agricultural abandonment is a major driver of change in rural landscapes. Assumed to provide beneficial results to the environment and the conservation of biota, rural abandonment triggers landscape and biotic homogenization and loss of valuable species and habitats. This article focuses on the ecological effects and conservation challenges of shifts in extensive

* This study was developed as part of the LIFE+ project "Higro" ("Demonstrative Actions for the Conservation of Priority Habitats in Northern Mountain Areas in Portugal"; LIFE09NAT/PT/000043). A.L. is supported by the Portuguese Science and Technology Foundation (FCT) through Postdoctoral Grant SFRH/BPD/ 80747/2011. Contact Angela Lomba at angelalomba@fc.up.pt. 
grazing regimes on marginal pastureland of Mediterranean mountains. We conceptualize a navigated socioecological transition toward conservationoriented management after the collapse of historical land systems. The article provides examples from the LIFE+ project "Higro," developed in mountainous protected areas in Portugal, of how management for conservation could sustain disturbance-dependent habitats. We argue that actively and regularly managing large habitat areas should be envisaged as a short-term approach to limit the immediate effects of rural abandonment. A gradual integration of conservation targets with other activities in changing rural economies is necessary to foster long-term conservation of species and habitats, building on the link between conservation-oriented habitat management and ecosystem services in rural landscapes. Conservation goals should run alongside recovery of social systems and innovation applied to traditional sources of income. This parallel development would contribute to building up social-ecological resilience by maintaining a diversity of social and ecological capital in rural areas.

\section{Introduction}

Understanding and managing ecological changes arising from the collapse of traditional farming systems represents one of the major current challenges in conservation biology (Beilin et al. 2014). With a large proportion of its Natura 2000 network of protected areas managed for agriculture, livestock, or forestry, the European Union (EU) faces the even bigger challenge of meeting global and regional conservation targets across a continent with a long history of human management (Beilin et al. 2014; Halada et al. 2011). This history explains why many of the most valued habitat types and biodiversity assets in Europe are currently dependent to some extent on the maintenance of sustainable farming and forestry systems (Halada et al. 2011). This need has triggered the adoption of key policy instruments, not only to face the negative effects of farming and forestry intensification but also to mitigate the conservation impacts of rural abandonment (Navarro and Pereira 2012).

In the wider context of rural abandonment and its consequences for marginal land across the European countryside, this article focuses on the ecological effects and conservation challenges triggered by changes in extensive grazing in marginal pastureland of Mediterranean mountains. We first review the recent trends of rural abandonment and the resulting challenges for nature conservation policy in the EU. Then we describe the main features of farming and grazing regimes in the context of agro-silvi-pastoral systems of Mediterranean mountains, and connect those features to landscape management and to the conservation of habitat types with the highest conservation value. We propose a simple conceptualization of a navigated socioecological transition toward conservation-oriented land management after the collapse of historical 
land systems. To illustrate the approach, we focus on the conservation of EU priority habitat types that are largely dependent on grazing and related disturbances. We provide examples from project "Higro," developed in Portugal and funded by the EU through the LIFE+ program, of how active management for conservation could compensate for the decline of grazing pressure in areas where the native herbivore fauna has been historically depleted. We conclude with a discussion of the opportunities, caveats, and sustainability of active management for conservation in social-ecological systems of changing rural regions.

\section{Rural Abandonment as a Challenge for Nature Conservation Policy}

\section{Farming and Biodiversity in a Rapidly Changing World}

Land-use changes driven by socioeconomic and environmental factors are among the most important pressures affecting biodiversity globally, due to their impact on landscape structure, function, and dynamics (Fédoroff et al. 2005). Farming activities impact species' richness and abundance, and have been highlighted as a key threat to biodiversity (e.g., Firbank et al. 2008; Tilman et al. 2001). Many studies have thus been developed focusing on how farming practices can be modified to mitigate negative impacts and generate benefits. Even so, there is a well-known conflict between noncrop biodiversity and cropped land, and handling the trade-offs between these elements represents today a central challenge in agroecosystem management (Firbank et al. 2008).

Considered the main type of management of terrestrial ecosystems toward maximizing one or a few provisioning ecosystem services, agriculture is expected to further increase during the coming decades to meet increasing food (and energy) demand around the world (Firbank et al. 2008; Millennium Ecosystem Assessment 2005). As agricultural intensification allowed mankind to feed the growing world population, it also became one of the main drivers of worldwide biodiversity decline (Brooks et al. 2006; Kleijn et al. 2009). Farmers are therefore increasingly receiving incentives for biodiversity conservation by policies encouraging the maintenance of extensive farming systems, the preservation of (semi)natural landscapes, or the extensification of intensive farming systems (Kleijn et al. 2009). At the same time, natural reserves and systems of protected areas are being created, aiming at protecting species and ecosystems from the impact of destructive human activities (Bennett, Radford, and Haslem 2006).

Worldwide, farming has become one of the dominant forms of disturbance shaping biotic communities throughout landscapes, with cultivated systems (i.e., areas where at least 30 percent of the landscape is in croplands, shifting cultivation, or confined livestock [Flinn, Vellend, and Marks 
2005; Millennium Ecosystem Assessment 2005; Queiroz et al. 2014]) currently covering about 38 percent of the Earth's terrestrial surface (Millennium Ecosystem Assessment 2005; Queiroz et al. 2014). While the environmental basis for agriculture, such as climate, soil type, and terrain, is relatively constant on a human time scale, other factors (e.g., demographic shifts, market preferences) are characterized by frequent changes (Dramstad et al. 2002). The multitude of factors causing change in the agricultural landscape is matched by an equally wide-ranging list of potential effects (Dramstad et al. 2002). Furthermore, projections under the Millennium Ecosystem Assessment (2005) development scenarios forecast an additional 10-20 percent of grasslands and forestlands to be converted primarily to agriculture by 2050 (see also Bennett et al. 2006) .

Land abandonment usually triggers an increase in the area occupied by seminatural vegetation types like scrubland and woodland (Bielsa, Pons, and Bunce 2005; Lasanta, Nadal-Romero, and Arnáez 2015). By promoting forest encroachment, agricultural abandonment can contribute to decreasing habitat diversity and simplifying landscape mosaics in their spatial heterogeneity (Flinn et al. 2005; Moreira et al. 2005; Vassilev et al. 2011). Thus, the process of vegetation succession can result in profound habitat modifications and ultimately lead to the loss of grassland and other open habitats due to overgrowth by shrubs and trees (Lasanta, Nadal-Romero, and Arnáez 2015; Lasanta, NadalRomero, Paz, et al. 2015; Plieninger 2006; Queiroz et al. 2014).

However, the consequences of land abandonment for landscape diversity and spatial patterns are still not fully understood (Bielsa et al. 2005; de Chazal and Rounsevell 2009; Pykälä et al. 2005; Queiroz et al. 2014), and those impacts have been considered dependent on the former uses of the landscape. A recent review of the effects of farmland abandonment on biodiversity conservation (Queiroz et al. 2014) highlighted that agricultural land is decreasing in Europe and North America, while an increasing trend has been observed for Asia and Central and South America, with negative impacts for biodiversity conservation reported for the EU region and Asia. In regard to Europe, Bolliger et al. (2007) described how the forestation of formerly open land in Switzerland may lead to a short-term increase in species richness (due to increased landscape heterogeneity), even if potentially causing the loss of habitat for open land species. Bielsa, Pons, and Bunce 2005 also observed beneficial effects of land abandonment on biodiversity in intensive rural landscapes of East Anglia, England. Moreover, seminatural habitats adjacent to traditional farmland depend on the continuation of extensive agricultural practices, and some of them are among the most species-diverse habitats of the landscapes in 
which they occur (Lomba et al. 2012). Conversely, abandonment in wood-pasture habitats was followed by loss of small-scale habitat diversity (Bergmeier, Petermann, and Schröder 2010; Vassilev et al. 2011).

Agricultural and pastoral abandonment has also been stressed as an opportunity for rewilding European landscapes, with potentially broader ecological benefits for both nature conservation and the provision of ecosystems services at continental and regional scales (Caraveli 2000; Henle et al. 2008; Jackson, Pascual, and Hodgkin 2007; Navarro and Pereira 2012).

\section{Rural Abandonment across Europe as a Challenge for EU Policy}

Rural landscapes are considered an essential asset for the maintenance of European biodiversity (Benton, Vickery, and Wilson 2003; Halada et al. 2011; Stoate et al. 2009; Tscharntke et al. 2005). For centuries, traditional agricultural systems shaped European landscapes, diversifying environmental conditions that eventually benefited a wide range of wild species and habitat types, many of which are of particular nature conservation concern and are highlighted as of conservation priority in the European Union's Birds and Habitats Directives (e.g., Halada et al. 2011; IEEP 2007). However, in recent decades broad-scale polarization has been observed in agricultural landscapes, with increasingly intensified use of already intensively managed land accompanied by the abandonment of more extensively used land (Bratli et al. 2006; Caraveli 2000; Robinson and Sutherland 2002).

The decrease of the economic significance of farming in many parts of Europe over recent decades, due to socioeconomic factors (e.g., globalization and mechanization [Bolliger et al. 2007]) and to the intrinsic limiting physical factors of the land (Bielsa et al. 2005; Brown and Kothari 2011; Caraveli 2000), was especially prominent in marginal mountainous areas (e.g., Mediterranean mountains) since the 1950s (Bielsa et al. 2005; Bolliger et al. 2007). These farmlands have been shaped by human-nature interactions over a long time (Bielsa et al. 2005; Brown and Kothari 2011; Plieninger 2006). Moreover, the traditional type of agriculture, characteristic of the subsistence economy, was adapted to the limiting factors and obstacles that the natural conditions imposed, and was partly responsible for maintaining high levels of biological diversity (Bielsa et al. 2005; Brown and Kothari 2011). Agricultural abandonment with its gradual decrease of agricultural practices has caused intrinsic changes in land management and modified rural landscapes. This process of abandonment involved different patterns of change, from partial abandonment of some parcels, creating a landscape mosaic of unused and cropped areas (Bielsa et al. 2005), to total 
abandonment of agriculture (and pastoralism) and a progressive transformation of the area into uncultivated land (MacDonald et al. 2000).

The recent concept of "high nature value" refers to farmlands characterized by the presence of certain land cover types (especially seminatural vegetation and mosaics of low-intensity crops) that make rural landscapes valuable for nature conservation (Beilin et al. 2014). These low-intensity agricultural landscapes, with physical (e.g., mountainous areas [Caraveli 2000; MacDonald et al. 2000]) or climatic handicaps (less-favored areas [Stoate et al. 2009]), have suffered progressive marginalization, extensification, and abandonment. Abandonment of this sort of land is recognized to affect biodiversity, as many of the farmland habitats of high nature value need to be actively managed, especially seminatural grasslands (Beilin et al. 2014). Scrub and forest encroachment is also known to alter water cycle regulation and the downstream provision of hydrological ecosystem services, namely by reducing total runoff (Carvalho-Santos, Honrado, and Hein 2014; García-Ruiz and Lana-Renault 2011; GarcíaRuiz et al. 2011). Regional specialization in production and intensification in some former high nature value farmlands, with subsequent abandonment in others, has been documented, and some of these landscapes are currently under threat, for example the typical agro-silvo-pastoral landscapes of southern Iberia (Stoate et al. 2009). As a large number of highly valued wildlife species and seminatural habitat types in Europe are partially dependent on extensively managed land, biodiversity in grazing land and extensive meadows is therefore threatened by reduced management (EEA 2010; Lasanta, Nadal-Romero, Paz, et al. 2015). In fact, 70 percent of all species of European interest for conservation are linked to agroecosystems and 76 percent of all EU Annex I habitat types (Habitats Directive, 92/43/CEE) currently have an unfavorable conservation status (Caraveli 2000; EEA 2010; Stoate et al. 2009).

\section{Traditional Land Uses and the Conservation of Priority Habitats in Mountain Rangeland}

Mediterranean climates have a strong handicap for farming: Warm temperatures and rainfall don't match in time. The rainfall is concentrated in winter, and the summers are long and dry. The favorable period for plant growth without irrigation is thus restricted to a small period in late winter and the beginning of spring, when almost all the dry matter is accumulated both in natural ecosystems and in agroecosystems (Bernués et al. 2011). Farming systems in mountainous regions were developed as a way to cope with this severe restriction on agriculture and livestock production. Mountains are known as "water towers" 


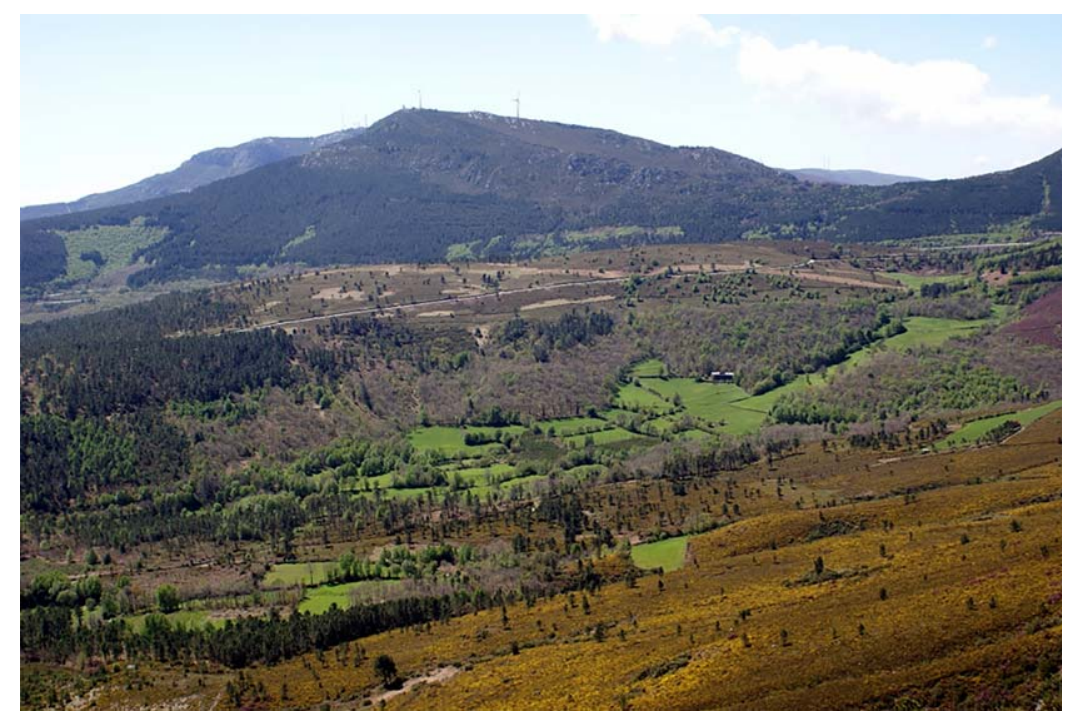

Figure 1. A Mediterranean Mountain Agricultural Region.

(Körner and Ohsawa 2005), and the water gathered at high elevations can be managed and diverted with a low effort to water meadows and crop fields. Combining watered plants with long sunny days and low atmospheric humidity boosts photosynthesis and reduces plant losses due to diseases (García-Ruiz and Lana-Renault 2011).

Mediterranean mountains are also a rather favorable environment for the integration of animal production and plant crops in agriculture systems (Figure 1). Altitude delays the timing of the maximum dry matter production of grasslands, so mountain pastoralism can be spatiotemporally integrated with milder lowland areas, where grassland plants never suspend their growth during the cold season (Pinto-Correia and Vos 2004). Elevation gradients in mountains provide green forage throughout the year, historically grazed by large flocks of transhumant animals, usually sheep. Alongside, higher precipitations and soil topographic gradients promote the development of hay meadows, a mosaic of water- and nutrient-demanding grasslands and their associated habitats (e.g., woodlands and edge herb communities [Lomba et al. 2012]). Vegetation mosaics of Mediterranean mountains are complex enough to satisfy and efficiently integrate the feeding needs of cattle, sheep, and goats (SilvaPando, Lorenzo, and Hernández 2002).

Soil fertility restoration was a major driver of the evolution of agriculture systems (Mazoyer and Roudart 2006). Compelling evidence shows that in an early stage, agriculture already faced severe soil fertility 
constraints in the Mediterranean Iberian Peninsula (Aguilera et al. 2008). Besides providing food and draft power, domestic herbivores were determinant in enhancing soil fertility in these traditional systems (Halstead 2014). This integration is probably a Bronze Age technological development (Mazoyer and Roudart 2006). A study in northeastern Portugal (Aguiar and Azevedo 2011) has shown that the area of cereals cultivated in traditional farming systems, before the introduction of chemical fertilizer, nitrogen, depended on the rangeland area pastured by sheep and cattle. For each hectare of the cereal-fallow crop system, approximately 6.5 hectares of corresponding rangeland was necessary. Communal rangelands acted as a source of plant nutrients, and animals as transport devices. This functional connection was however broken with the introduction of chemical fertilizers, which together with the rural exodus and the evolution of market-oriented farming has triggered the collapse of these integrated farming systems and subsequent landscape changes (Pinto-Correia and Vos 2004).

\section{Collapse of Farming Systems, Landscape Dynamics, and Conservation Challenges}

The abandonment of farming activities could easily be assumed to provide beneficial results to the environment and to the conservation of the biota, as a natural rewilding process is expected to follow. However, postabandonment vegetation dynamics is greatly dependent on the initial state of the system and on the characteristics of the previously prevailing disturbance regime (Debussche, Lepart, and Dervieux 1999; Queiroz et al. 2014). Farming, especially when intensive and continuous, can lead to local or even regional extinction of species, promote the spread of exotic invasive species, and drive changes in the environment (soil, topography, etc.), among other effects (Lomba et al. 2012; Navarro and Pereira 2012). These alterations can be so profound that they can compromise the reestablishment of the natural systems due to the loss of their intrinsic resilience (Debussche et al. 1999).

Secondary succession is a particular type of vegetation dynamics that is usually triggered by some kind of disturbance. While some human disturbances can destroy vegetation and impede its restoration (e.g., in crop fields), less intensive activities such as extensive grazing, mowing, or logging will allow the regrowth of natural vegetation. In these systems, even if the structure and composition of the vegetation are affected, the reshaped formations are predominantly composed of natural flora, thereby representing important biodiversity reservoirs (Pärtel, Bruun, and Sammul 2005). 
The disturbances provoked by those activities frequently mimic natural disturbances that exist or existed for a long time. In fact, cattle grazing, mowing, and logging replicate the natural disturbances produced by the herbivorous megafauna that was widespread in Europe before the Holocene (Vera 2000). It is probable that this megafauna coevolved with plant species that adapted to the frequent cuttings caused by those animals. Areas of local water accumulation must have concentrated herds of large herbivores, especially in the Mediterranean climate, where such areas are less frequent, but also in temperate climates. This conclusion is consistent with the great number of species adapted to herbivory that constitute the hygrophilous meadows widespread throughout Europe (Pärtel et al. 2005). These seminatural vegetation types contain a specialized biodiversity that is now threatened by the abandonment of grazing activities (Lomba et al. 2012).

The effects of agricultural and pastoral abandonment are particularly manifested on plant communities and vegetation mosaics dependent on disturbance regimes related to farming or grazing (Lasanta et al. 2009). In the mountains of Portugal, shrub invasion is pervasive on former agriculture fields, rangelands, and hay meadows (Azevedo et al. 2011), leading to the reduction of the cover area of annual and perennial grasslands, hay meadows, and all types of animal and man-made vegetation. In the nature conservation policy of the $\mathrm{EU}$, these vegetation types correspond to several habitat types protected under the Habitats Directive. Examples are the biodiverse, low-intensity hay meadows (habitats 6510 and 6520; "Lowland hay meadows" and "Mountain hay meadows," respectively) the endemic rich grasslands of Iberian mountains (6160; "Oro-Iberian Festuca indigesta grasslands"); and even priority habitat types such as temperate wet heaths $(4020 *$; "Temperate Atlantic wet heaths with Erica ciliaris and Erica tetralix"), pseudosteppes with grasses and annuals (6220*; "Xeric sand calcareous grasslands"), and species-rich Nardus grasslands (6230*; "Species-rich Nardus grasslands, on siliceous substrates in mountain areas"). The extent, quality, and connectivity of these habitat types will be affected over large areas by the collapse of mountain farming systems (Halada et al. 2011).

The expected postabandonment recovery of native forests, although apparent in the landscape, is currently less than anticipated. For example, in Portugal, between 1995 and 2010, Quercus species, the dominant trees of Portuguese climax forests, had a net area loss of more than 70,000 hectares, whereas shrublands and pastures increased by over 300,000 hectares (Honrado et al. 2011). The main driver of this trend may have been wildfires, an important driver of vegetation and soil conditions in Portugal (e.g., Prats et al. 2014). In the same period, the 
mean burned area in Portugal was 132,445 hectares, corresponding to 1.5 percent of the country's mainland area and 2 percent of the forest area (Honrado et al. 2011). Fire disturbance is keeping large areas of abandoned or extensively used rangeland in a monotonous vegetation steady state, dominated by fire-prone shrubs (mainly of Cistus and Erica species [Lasanta, Nadal-Romero, and Arnáez, 2015; Lasanta, NadalRomero, Paz, et al. 2015; Lloret et al. 2002; Loepfe et al. 2010]). The recovery of native forests has also been delayed by the lack of propagule pressure. Quercus trees have historically been depleted in large areas of the Portuguese landscape, and all Quercus species are barochorous, with slowly dispersing diaspores (Johnson, Shifley, and Rogers 2002).

A successful pathway from a traditional land management system toward a future conservation-oriented management system can be conceptualized as a navigated socioecological transition (sensu Chapin et al. 2010; see Figure 2). In the traditional land system, which was in place until the twentieth century, the provision of valuable goods such as food, fiber, wood, or water was at the core of land management options; the conservation of habitats and biodiversity was a side benefit resulting from the marginal character of the land and extensive nature of most management actions (Figure 2a). The rural exodus and the external input of ecosystem and nonecosystem services (sensu Cumming et al. 2014) resulted in a gradual abandonment of farming, grazing, and other land management activities. This disconnection between people and local resources meant the collapse of the traditional system, which in turn resulted in increased vulnerability of many habitats and species to succession, wildfires, and other ecological change processes (Figure 2b). Active management with underlying conservation goals places nature conservation at the center of land management decisions, but it is highly dependent on external inputs (namely financial) into the system; regulation and cultural and some provisioning ecosystem services may also benefit from conservation-oriented policy and management, fostering the future sustainability of this novel land management paradigm (Figure 2c).

The general socioecological model described above is illustrated in the next section with the conservation of disturbance-dependent habitat types. In the wider context of the collapse of the historical land management system, the specific challenge addressed here is the abandonment of pastoralism and the downstream threats to the conservation of two priority habitat types in extensive pastureland. The next section describes and discusses a conservation-oriented active management strategy designed and implemented in Portuguese mountains during an EU-funded LIFE project. 


\section{(a) Traditional agro-silvi-pastoral system}

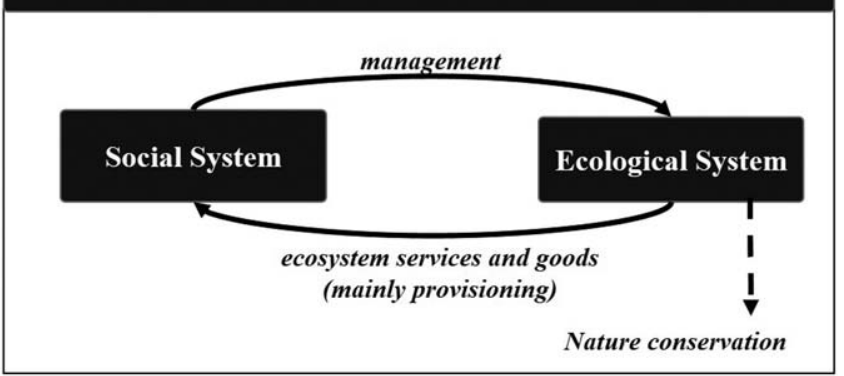

(b) Abandonment of agro-silvi-pastoral system

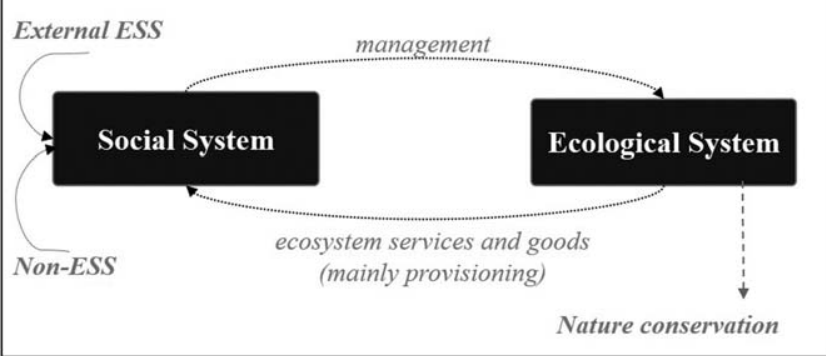

\section{(c) Management for nature conservation}

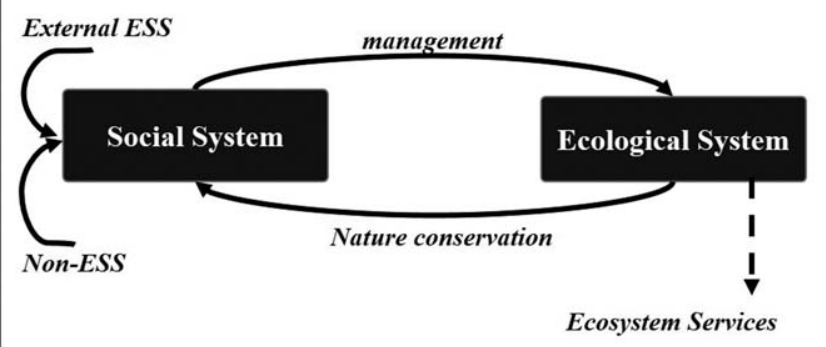

Figure 2. The Navigated Socioecological Transition to a Conservation-Oriented Management System. ESS, ecosystem services.

\section{Conservation of Priority Habitats after Abandonment of Pastoralism in Mediterranean Mountains of Portugal}

Setting the Scene: Collapse of Farming Systems and the Conservation of Disturbance-Dependent Habitats

Portuguese mountains are located at the transition between two major biogeographic regions of Europe (Atlantic and Mediterranean), with a 
gradual eastward transition from a temperate Atlantic to a Mediterranean type of climate. This dichotomy is well reflected in the vegetation cover composition and in the structure of agro-silvo-pastoral systems. In these mountain areas, the land abandonment process is most evident on rangeland areas historically managed through extensive grazing. Large areas of those rangelands were dominated by an early-successional low scrub of Ericaceae and Leguminosae shrubs (Silva-Pando et al. 2002). Ulex minor, a low prickly legume shrub with nutritious sprouts (Silva-Pando, GonzálezHernández, and Castro Garcia 1999), played a rather important role. In each Portuguese mountain range there is an endemic cattle breed that has adapted to $U$. minor grazing, a form of management in which the cattle are taken to the communal pastoral areas and left to graze the nutritious sprouts in early spring and then to feed on the Gramineae that have a later growth period (Silva-Pando et al. 2002). Cattle density in traditional mountain farming systems depended on the amount of hay gathered in early to middle summer in private hay meadows that was used to feed animals during the winter (Santos and Aguiar 1995).

Communal land played an important part in the cattle production system, as it was grazed by cattle, sheep, and goats. Most of those communal rangelands are located on mountaintops and are colonized by Ericaceae heathland, usually in mosaic with palatable perennial grasses (e.g., Agrostis and Festuca species). Some of those communal pastures are situated in flatter land and are covered by a humid, nutrient-poor, shallow peat mosaic of Atlantic heathlands and Nardus grasslands, which represent two priority habitat types in the EU conservation policy (see the next section). Although less productive than hay meadows, and yielding a forage with lower palatability and digestibility, these vegetation mosaics played an important role in cattle and sheep feeding during summer and are the habitat of important plant species like the strict endemic Festuca henriquesii (Meireles, Pinto-Gomes, and Cano 2012).

The persistence and function of hay meadow, heath, and grassland habitats in Iberian mountains are directly connected with dairy and meat production. These economic sectors have been quite stable during recent years in Portugal, even though there is a tendency for a decline in cattle numbers and for the substitution of beef cattle for dairy cattle (Bielsa et al. 2005). Production systems have also changed, as the decline of rye and potato crops following Portugal's EU adhesion released agricultural land for feed crops (Lomba et al. 2010). Today cattle number per holding relies more on the existing arable land area than on haymeadow area. Sheep livestock underwent a massive regression in Portugal. Therefore, remote meadows and Nardus grasslands are in a process 
of abandonment and shrub encroachment. Many meadows located close to villages were converted to arable cropping or intensified through irrigation and mineral nutrient use. However, for methodological reasons this intensification-extensification dynamic is difficult to grasp in Portuguese agricultural statistics (Aguiar and Seita Coelho 2014).

The conservation challenges described above motivated the development of project "LIFE-Higro-Demonstrative Actions for the Conservation of Priority Habitats in Northern Mountain Areas in Portugal." In this project financed by the LIFE+ program of the EU, several types of actions have been implemented and evaluated for the active management of two priority annex 1 habitats that are organized in dense, disturbancedependent mosaics: "Temperate Atlantic wet heaths with Erica ciliaris and Erica tetralix" (habitat type 4020*) and "Species-rich Nardus grasslands, on siliceous substrates in mountain areas" (habitat type 6230*). The project was carried out between 2011 and 2014 in three mountainous special areas of conservation of northern Portugal, with the ultimate goal of developing a strategy for the conservation of these habitat mosaics through active management to overcome the effects of decreased grazing pressure (see Table 1, Figure 3). These three areas were selected for three main reasons: (1) They include some of the best representations of the focal habitat types in the country; (2) they cover a key climatic gradient in the region, from temperate Atlantic in the northwestern Arga site to Mediterranean in parts of the southernmost site (Montemuro); and (3) previous interactions with local stakeholders facilitated the collection of data and the implementation of active management actions.

The general strategy and workflow of LIFE-Higro included the following activities: (1) a survey of local trends and farmers' perceptions of pastoralism; (2) development of detailed habitat mappings and biodiversity surveys (e.g., Gonçalves et al. 2016); (3) tailored definition of conservation goals, targets, and indicators; (4) planning and implementation of conservation-oriented active management actions; and (5) assessment of effectiveness of those actions through targeted monitoring. The next sections describe and discuss some of these activities.

\section{Conservation of Priority Habitats through Active Management in LIFE-Higro}

\section{Local Perception of Recent and Future Trends in Pastoral Activities}

We first conducted a questionnaire-based survey in the three mountain special areas of conservation covered by the project, to investigate the perceptions and expectations of residents from local mountain communities regarding the decline of pastoral activities. According to 
114 Rural Sociology, Vol. 82, No. 1, March 2017

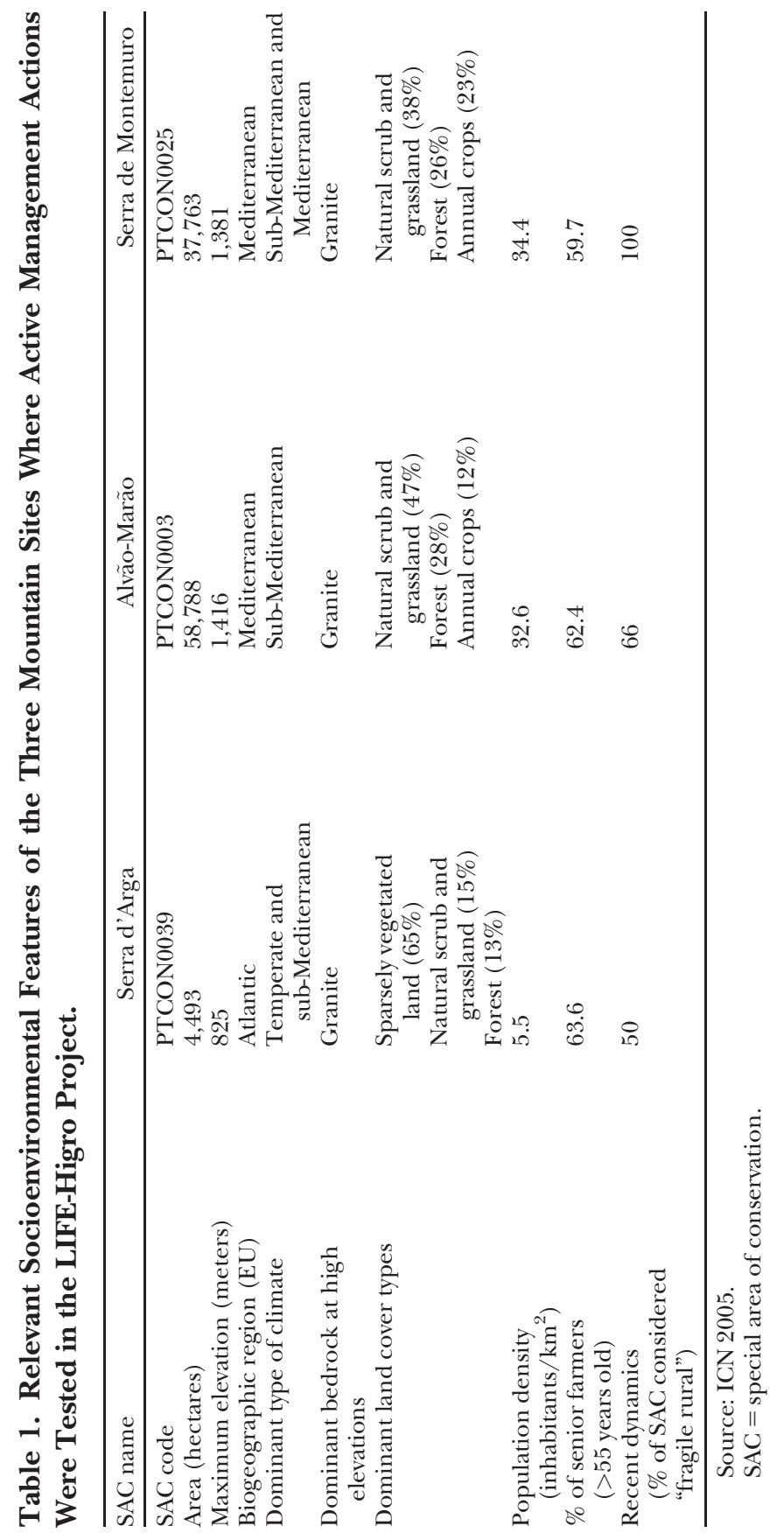



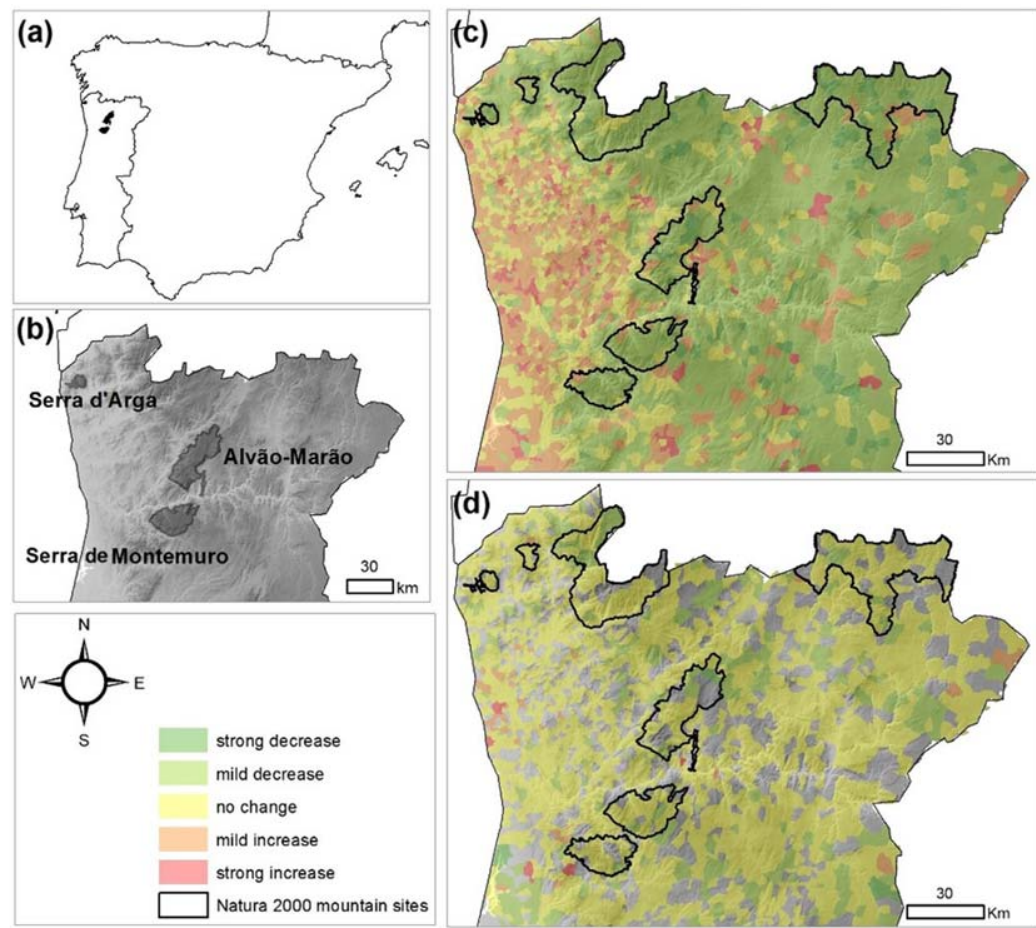

Figure 3. Areas of the LIFE-Higro Project. The three sites of the project LIFE-Higro in the Iberian Peninsula (a) and in the North of Portugal (b). The maps on the right represent recent variations (1999-2009) in resident population density (c) and in livestock units (d), with the strength of such variation standardized and expressed as distinct tones. Regional Natura 2000 mountain sites are highlighted.

respondents, over the last 40 years livestock numbers have steadily decreased. This decreasing trend of livestock number has been accompanied by a decrease in the number of shepherds. Nonetheless, 77 percent of shepherds surveyed said they still use the grazing land in the mountain. In parallel, stabled livestock in these areas has remained the same for goats and sheep, but has increased for bovines. Of those using the area for pasturing, 83 percent pasture their livestock weekly, but only 7 percent do it more frequently. Remarkably, most respondents revealed that they would not consider abandoning the activity in the next 5 to 10 years, regardless of possible subsidy cuts. However, roughly half of respondents mentioned that they had no family member to continue the activity. 
Local residents describe a present landscape with much more shrubland than 40 years ago. Bedding for livestock was by far the main reason for shrub cutting ( 87 percent), followed by maintenance of open spaces (10 percent) and renovation of pasture areas (3 percent). Roughly half the respondents identified fire as a fundamental tool in renovating pasture area. All individuals were able to identify the various dominant plants as well as the habitats of highest conservation value, and overall they categorized the project areas as of high to moderate conservation value. Although local residents were able to identify the natural value and those elements of conservation priority, 93 percent were unaware of the mountain range conservation status.

The results from the questionnaire-based survey suggest that local shepherds are well aware that the grazing land in the project areas have undergone changes over recent decades, mainly through the reduction of grazing pressure and local land use. According to residents, the reduction of grazing pressure is directly linked to a decrease in the number of shepherds. As a consequence of these changes, traditional practices such as the cutting of heath have decreased, leading to scrub and forest encroachment. These changes have been reported in other pastoral systems throughout Europe, and found to have a negative impact on the ecological quality and biodiversity associated with pastoral agroecosystems (Bernués et al. 2005; Casasús et al. 2007). Considering present and possible future trends of decreased pastoral activity should thus be a focus of future management strategies, provided that adequate grazing pressures are contemplated when designing conservation policies.

\section{Defining the Conservation Goals and a Strategy to Achieve Them}

Grassland ecosystems are a very important part of Europe's natural capital, since they offer ideal conditions for a vast diversity of species and provide several valuable ecosystem services, from meat and dairy production to carbon sequestration (Plieninger and Bieling 2013). Many European grassland habitats are maintained through grazing or cutting, but recent changes in cropping and grazing pressures are threatening the diversity and abundance of these ecosystems (Silva et al. 2008). In fact, many grassland habitats are fully dependent on active management (Halada et al. 2011).

The conservation of these habitats is not always easy due to the need of shepherds and landowners to improve their pastures, and thus encourage the growth of more productive species with greater digestibility (Blackstock et al. 1999). As a rule, grasslands used for intensive 


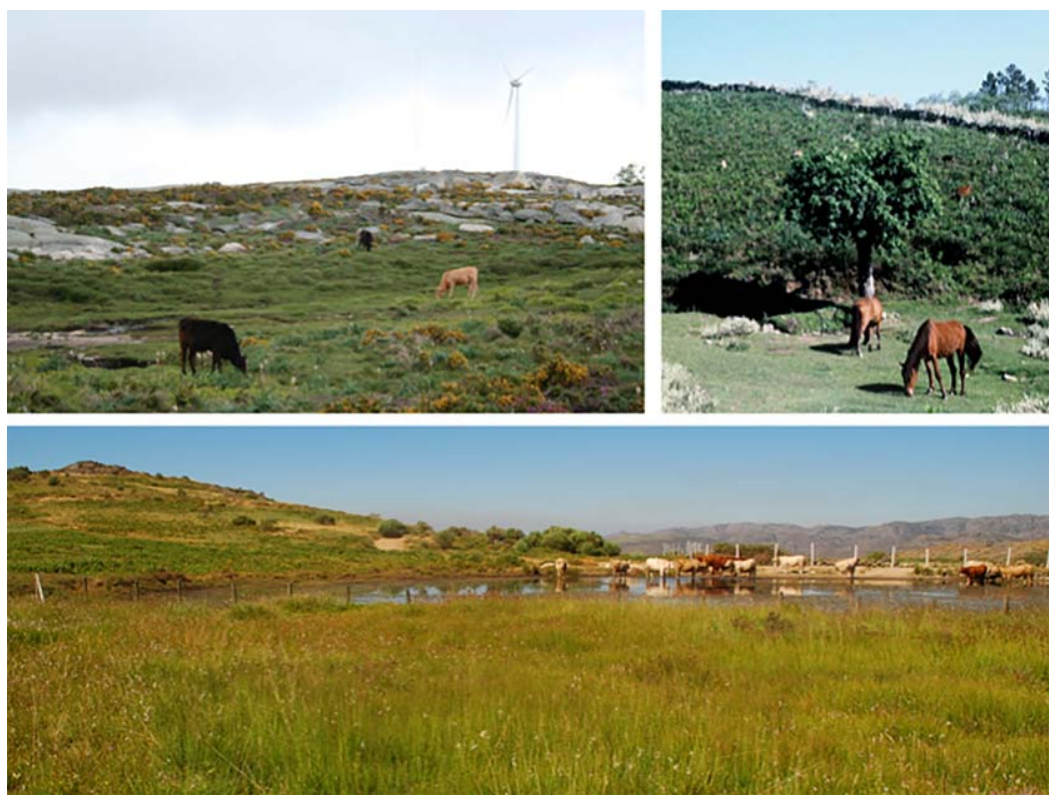

Figure 4. Sustainability of Grazing Systems Using Different Types of Livestock.

production are abundantly fertilized with nitrogen and phosphorus to increase the production and quality of forages. This practice is often incompatible with the objective of creating or maintaining species-rich vegetation (Peeters and Janssens 1998). And as regular consumption of the foliage by livestock grazing is required, it has often been suggested that the best way to maintain seminatural grasslands would be the maintenance of traditional management measures. However, the low quality of the forage has been highlighted as a constraint to continued management of these pastures (Isselstein, Jeangros, and Pavlu 2005).

Long-term agricultural and ecological sustainability of grazing systems results from maintaining an appropriate species balance, which can be achieved by using different types of livestock (Figure 4), because animals are born with a digestive system architecture that makes some plants better forage than others (Launchbaugh and Walker 2006). Horses eat mainly fibrous grasses, avoiding forbs with toxic metabolites, and can eat at the ground level due to their double dentition. Cows have large broad mouths and large rumens well suited for harvesting and digesting herbaceous plants, but cannot graze very short vegetation because they need to pull the forage with their tongue. The narrow mouths of sheep make them well suited for eating forbs, but they avoid grasses with low digestibility, such as Nardus. Goats are particularly well 
designed for eating shrubs and have a good capacity for detoxifying the tannins and terpenes often found in shrubs (Launchbaugh and Walker 2006). Thus, a key mechanism by which livestock affect the biodiversity of pastures is the creation and maintenance of structural heterogeneity of grasslands as a result of differential dietary choice (Rook et al. 2004). Selecting the appropriate livestock species for grazing introduces opportunities for plant species with different functional characteristics, which is fundamental to the conservation of some types of seminatural pastures, such as species-rich Nardus grasslands (Rook et al. 2004).

It has been demonstrated that maintaining the diversity of European grasslands depends on some kind of regular physical disturbance (de Bello et al. 2010). There is evidence that moderate grazing helps to maintain the diversity of plants, reducing the abundance of dominant species (de Bello et al. 2010; Klimek et al. 2007; Lasanta, Nadal-Romero, and Arnáez, 2015). Nonetheless, other factors can influence the species richness and composition of grassland communities, such as topography, the intensity of solar radiation, and soil chemical heterogeneity and fertility (Klimek et al. 2007).

Understanding the different functional characteristics of plant species and their response to disturbances is a key asset in defining a consistent management strategy (de Bello et al. 2010). For example, Agrostis capillaris is a perennial grass with wide ecological amplitude, able to survive in soils of moderately acidic $\mathrm{pH}$, and which can renew the foliage very quickly even under intensive grazing; it is very competitive with the addition of nitrogenous compounds to the soil and can become dominant in disturbed environments (Duprè et al. 2010; Grime, Hodgson, and Hunt 1988). Danthonia decumbens is a perennial grass typical of slow growth in Nardus grasslands and other communities of oligotrophic environments, being absent in fertile soils due to these grasses' low competitiveness; despite being quite palatable, it is very sensitive to overgrazing due to its slow growth (Grime et al. 1988). Conversely, Nardus stricta, a perennial grass species typical of acidic, well-drained soils, is unpalatable to most herbivores, especially sheep. This grass can proliferate by seed or vegetative growth after a disturbance such as fire, but it is sensitive to recurring fires and cuttings (Fischer and Wipf 2002; Grime et al. 1988).

\section{Main Actions and Findings during Project LIFE-Higro}

Under project LIFE-Higro, four types of actions (Figure 5) were implemented and evaluated for the active management of the two focal priority annex 1 habitat types, that is, temperate Atlantic wet heaths $\left(4020^{*}\right)$ and species-rich Nardus grasslands (habitat 6230*). Those actions were 


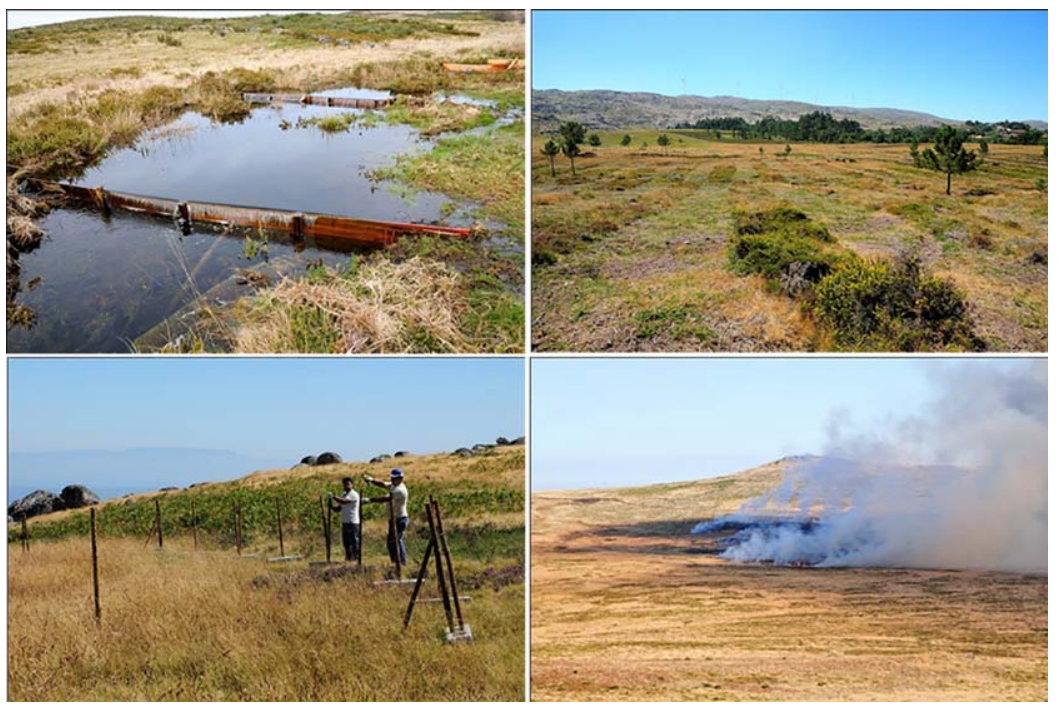

Figure 5. Different Activities Carried Out in the LIFE-Higro Project.

carried out between 2011 and 2013 on approximately 162 hectares, distributed in three mountainous special areas of conservation in northern Portugal (see Figure 2 and Table 1). As the conservation of these habitats largely depends on frequent disturbance preventing their progression toward more advanced successional stages (scrub or woodland), the project tested the effects of two traditional management activities historically performed by local farmers: extensive grazing and vegetation cutting. However, too much grazing or cutting pressure could lead to a strong decline of wet heaths and to a decrease in habitat quality for Nardus grasslands. Thus, to control grazing and cutting pressure, fences were installed in some of the areas. The degradation of drainage patterns also required the local restoration of natural hydrology. The effectiveness of all these actions is under continuous evaluation based on statistically designed monitoring schemes.

Mechanical and manual control of shrubby and herbaceous vegetation was carried out on about 50 hectares, mainly using portable gasoline grass mowers; we aimed to evaluate the effects of nonselective interventions on promoting plant diversity and populations of threatened invertebrates. The open spaces in the vegetation created by cutting would favor some species that otherwise would have been negatively selected in competition with the shrub species. Thus, in each special area of conservation, we installed test areas to monitor the evolution of plant communities as well as to evaluate the effect of the vegetation cutting in the 
populations of the threatened Alcon Blue butterfly (Phengaris alcon) in Montemuro and Alvão-Marão. Preliminary results suggest that cutting favored herbaceous species typical of Nardus grasslands such as Polygala serpyllifolia and Galium saxatile, which occupy the small spaces created by cutting. Other species, such as grasses with a rather slow growth cycle, were however not favored by mechanical cutting.

Given the tendency for steep decline of grazing in mountain areas and considering that activities that promote biodiversity should be financially supported, the project tested a methodology of awarding compensation to shepherds through the provision of contract services that enable the continuity of their activity with clear conservationoriented objectives and rules. Accordingly, we contracted 158 hectares to ensure the continuity of extensive grazing as a method of active management of habitats. The effect of grazing and vegetation cutting on the flora, invertebrate fauna, and habitat quality is the subject of an evaluation study in test sites designed specifically for this purpose. The close and trusting relationships established with the shepherds will allow that, in the future, grazing areas of this project can sustain highquality habitats and their associated species.

The installation of 8.6 kilometers of fixed and removable fences had as its main objective the management of grazing activity, namely controlling its intensity and frequency so as to maintain habitat quality as well as a balanced representation of the two priority habitats in the mosaic. These structures were built in strategic locations to allow the protection of sensitive areas that require the absence of disturbance by cattle in order to allow the recovery of degraded habitat patches, especially in areas affected by overgrazing. These fences also enable the creation of experimental conditions to evaluate the evolution of plant communities and the impact of the various measures on the populations of threatened invertebrates. Some of the first results suggest that woody species are promoted with the absence of grazing, which is particularly evident in the case of the fast-growing Ulex minor, thereby promoting not only habitat quality (for habitat $4020^{*}$ ) but also forage quality.

Since the two target habitats are dependent on a high level of moisture in the soil for a large part of the year, we considered restoring microtopography an important action, namely regulating the water supply and the drainage patterns that were in some cases altered by human action. In this regard, restoration of the natural hydrology was done on 124 hectares through the installation of 152 structures: 144 wood board or recycled PVC dams and 8 live fascines. As with the other actions, we are still assessing the effect of these interventions on the habitats and populations of invertebrates (e.g., Southern Damselfly, Coenagrion mercuriale). There were 
no significant changes registered in the areas where natural hydrology was restored, probably due to the short time since the experiment was done.

\section{Conclusions and the Way Forward}

\section{Conservation through Active Management:-Lessons from Project LIFE-Higro}

Grazing activities influence vegetation and habitats through various processes, not always noticed immediately and operating at different spatial and temporal scales, controlling the structure and composition of pastures as well as their productive potential (Diaz et al. 2006). The mechanisms by which those processes operate are varied, from aerial biomass removal by grazers to trampling that influences the compaction of the topsoil, or even creates voids that allow the development of less competitive species. Grazing also has a strong influence on biogeochemical cycles and the movement of nutrients (Hobbs 2006). For all these reasons, the active management of pastoral land is essential for the conservation of habitat biodiversity and functionality in mountain rural landscapes, many of which have been designated for nature conservation through national and international policy. The grazing of livestock in upland areas is an effective tool for the management of the territory, provided that the conditions that allow the ecological sustainability of the managed territories are maintained (Milchunas, Sala, and Lauenroth 1988). Furthermore, some of the most visually appealing mountain landscapes (important for tourism and thus potentially for local economies) are the result of an ancient interaction between plants and herbivores, which has been shaped by human action over time.

Conservation-oriented, active management of valuable disturbancedependent habitats endangered by succession and other processes triggered by rural abandonment can contribute to conservation goals in the absence of natural or human disturbance regimes capable of sustaining those habitats as well as their specialist biodiversity (Halada et al. 2011; Lasanta, Nadal-Romero, Paz, et al. 2015). Although the short time since implementation does not allow final conclusions, infield observations and preliminary results from targeted monitoring schemes in the LIFE-Higro project suggest that the tested management actions do promote habitat extent and quality, thereby contributing to EU-wide conservation goals. Moreover, there are other positive socialecological effects of active management beyond those related to the conservation of valuable habitats and of otherwise endangered flora and wildlife. Examples of those positive effects are the management of wildfire hazard in fire-prone landscapes, the maintenance of traditional 
ecological knowledge systems and of their associated rural technologies through blending with innovation, and the celebration of local cultural systems and the enhancement of agroecological tourism (Poláková et al. 2011). There is thus a strong link between conservation-oriented habitat management and ecosystem services in the wider countryside landscape.

However, actively and regularly managing large habitat areas can be a costly activity, and so it is likely unsustainable in the long term if focused only on achieving conservation goals. It is instead envisaged as a short-term, "emergency" approach to limit the immediate effects of rural abandonment on the extent, status, and connectivity of those habitats that have been sustained by farming and grazing activities, especially in areas where the wild herbivore fauna has been historically depleted, and where other sources of disturbance (e.g., wildfires) can potentially lead to severe ecological degradation. Instead, a gradual integration of conservation targets with other activities in changing rural economies will be necessary to ensure the long-term conservation of species and habitats. The demonstrative nature of LIFE-funded projects, the close link with rural development policies, and the humannature harmonization embedded in the vision underlying Natura 2000 are important assets for the future sustainability of nature conservation in Europe (Poláková et al. 2011).

\section{The Future: Integrating Habitat Management into Local Economies}

Effectively integrating habitat and biodiversity conservation into local economies and social systems may be thus the way forward toward sustainable management of disturbance-dependent habitats and species as part of local, dynamic social-ecological systems (Navarro and Pereira 2012; Plieninger and Bieling 2013). Adding to their high nature value, mountain countryside landscapes are providers of multiple ecosystem services, benefiting local residents and populations in lowlands. They are thus important to maintain as an important part of policy instruments aiming to meet social, economic, and environmental goals across the EU (Navarro and Pereira 2012; Plieninger and Bieling 2013).

With its rugged territory, Portugal is a good example of this kind of landscape, as mountains and other areas above 700 meters constitute 11 percent of the country's total surface area. This land is too vast and produces too many important ecosystem services to be left abandoned. In the previous sections we argued that farmland abandonment and the reduction of grazing pressure below critical values will have a relevant negative impact on mountain ecosystem services, including the 
biodiversity refuge service. The recovery of grazing in mountains is, however, a complex subject and must be coupled with the maintenance or recovery of agriculture. Besides EU direct aids and the development of geographical indications and traditional specialties-protected designation of origin, protected geographical indication, and traditional specialties guaranteed-there are other paths to be explored. First, the access to land by new farmers has to be facilitated (EC 2006). Also, the externalities of land abandonment (e.g., wildfires) are currently not paid for by absent landowners. This situation is a direct driver of a rigid land market that is unfriendly to investment in agriculture and animal rearing.

Roughly 5 percent of the Portuguese surface is communal property, concentrated in mountains of the northern half of the country. The Portuguese common land law is currently under revision, change that will introduce clear rules in the access of common land goods and in the definition of a common land user. These are fundamental steps toward more sustainable and shared management of resources on common land (Ostrom et al. 1999). At the agriculture system level, examples of solutions to promote grazing could be soil $\mathrm{pH}$ correction, an increase of the soil bioavailable phosphorous stock, the enlargement of the area sown with permanent pastures rich in legumes, and the generalization of fencing.

Direct payments for ecosystem services and targeted subsidies from rural development programs would add to the panoply of possible paths to ensure the sustained conservation of Europe's countryside habitats and biodiversity as part of a novel economic paradigm for mountains and other marginal areas (Poláková et al. 2011). Conservation goals should be met alongside the recovery of social systems, creation of new activities and job opportunities in rural communities, and recovery of traditional sources of income through innovation. This would further contribute to building up social-ecological resilience by maintaining a diversity of social and ecological capital in rural regions (Plieninger and Bieling 2013).

\section{References}

Aguiar, Carlos and J. C. Azevedo. 2011. "A floresta e a restituição da fertilidade do solo nos sistemas de agricultura orgânicos tradicionais do NE de Portugal." Pp. 99-117 in Florestas do norte de Portugal: História, ecologia e desafios de gestão, edited by João Pedro Tereso, João Pradinho Honrado, Ana Teresa Pinto, and Francisco Castro Rego. Porto, Portugal: InBIO.

Aguiar, Carlos and I. Seita Coelho. 2014. "Mountain Meadows." Pp. 218-20 in Grasslands and Herbivore Production in Europe and Effects of Common Policies, edited by C. Huyghe, A. De Vliegher, B. van Gils, and A. Peeters. Versailles, France: Editions Quae.

Aguilera, M., J. L. Araus, J. Voltas, M. O. Rodríguez-Ariza, F. Molina, N. Rovira, R. Buxó, and J. P. Ferrio. 2008. "Stable Carbon and Nitrogen Isotopes and Quality Traits of 
Fossil Cereal Grains Provide Clues on Sustainability at the Beginnings of Mediterranean Agriculture." Rapid Communications in Mass Spectrometry 22:1653-63.

Azevedo, J. C., C. Moreira, J. P. Castro, and C. Loureiro. 2011. "Agriculture Abandonment, Land-Use Change and Fire Hazard in Mountain Landscapes in Northeastern Portugal." Pp. 329-51 in Landscape Ecology in Forest Management and Conservation: Challenges and Solutions for Global Change, edited by C. Li, R. Lafortezza, and J. Chen. New York: Springer.

Beilin, R., R. Lindborg, M. Stenseke, H. M. Pereira, A. Llausûs, E. Slätmo, Y. Cerqueira, L. Navarro, P. Rodrigues, N. Reichelt, N. Munro, and C. Queiroz. 2014. "Analysing How Drivers of Agricultural Land Abandonment Affect Biodiversity and Cultural Landscapes Using Case Studies from Scandinavia, Iberia and Oceania.” Land Use Policy 36: 60-72.

Bennett, A. F., J. Q. Radford, and A. Haslem. 2006. "Properties of Land Mosaics: Implications for Nature Conservation in Agricultural Environments." Biological Conservation $133(2): 250-64$.

Benton, T. G., J. A. Vickery, and J. D. Wilson. 2003. "Farmland Biodiversity: Is Habitat Heterogeneity the Key?" Trends in Ecology and Evolution 18(4):182-88.

Bergmeier, E., J. Petermann, and E. Schröder. 2010. "Geobotanical Survey of WoodPasture Habitats in Europe: Diversity, Threats and Conservation.” Biodiversity and Conservation 19(11):2995-3014.

Bernués, A., J. L. Riedel, M. A. Asensio, M. Blanco, A. Sanz, R. Revilla, and I. Casasús. 2005. "An Integrated Approach to Studying the Role of Grazing Livestock Systems in the Conservation of Rangelands in a Protected Natural Park (Sierra de Guara, Spain)." Livestock Production Science 96:75-85.

Bernués, A., R. Ruiz, A. Olaizola, D. Villalba, and I. Casasús. 2011. "Sustainability of Pasture-Based Livestock Farming Systems in the European Mediterranean Context: Synergies and Trade-offs." Livestock Science 139(1):44-57.

Bielsa, I., X. Pons, and B. Bunce. 2005. "Agricultural Abandonment in the North Eastern Iberian Peninsula: The Use of Basic Landscape Metrics to Support Planning." Journal of Environmental Planning and Management 48(1):85-102.

Blackstock, T. H., C. A. Rimes, D. P. Stevens, R. G. Jefferson, H. Robertson, J. Mackintosh, and J. J. Hopkins. 1999. "The Extent of Semi-natural Grassland Communities in Lowland England and Wales: A Review." Grass and Forage Science 54:1-18.

Bolliger, J., F. Kienast, R. Soliva, and G. Rutherford. 2007. "Spatial Sensitivity of Species Habitat Patterns to Scenarios of Land Use Change (Switzerland)." Landscape Ecology 22(5):773-89.

Bratli, H., T. Økland, R. H. Økland, W. E. Dramstad, R. Elven, G. Engan, W. Fjellstad, E. Heegaard, O. Pedersen, and H. Solstad. 2006. "Patterns of Variation in Vascular Plant Species Richness and Composition in SE Norwegian Agricultural Landscapes." Agriculture, Ecosystems and Environment 114(2-4):270-86.

Brooks, T. M., R. A. Mittermeier, G. A. B. da Fonseca, J. Gerlach, M. Hoffmann, J. F. Lamoreux, C. G. Mittermeier, J. D. Pilgrim, and A. S. L. Rodrigues. 2006. "Global Biodiversity Conservation Priorities." Science 313(5783):58-61.

Brown, J. and A. Kothari. 2011. "Traditional Agricultural Landscapes and Community Conserved Areas: An Overview." Management of Environmental Quality: An International Journal 22(2):139-53.

Caraveli, H. 2000. "A Comparative Analysis on Intensification and Extensification in Mediterranean Agriculture: Dilemmas for LFAs Policy." Journal of Rural Studies 16(2):23142.

Carvalho-Santos, C., João Pradinho Honrado, and L. Hein. 2014. "Hydrological Services and the Role of Forests: Conceptualization and Indicator-Based Analysis with an Illustration at a Regional Scale." Ecological Complexity 20:69-80.

Casasús, I., A. Bernués, A. Sanz, D. Villalba, J. L. Riedel, and R. Revilla. 2007. "Vegetation Dynamics in Mediterranean Forest Pastures as Affected by Beef Cattle Grazing." Agriculture, Ecosystems and Environment 121:365-70. 
Chapin, F. S., III, S. R. Carpenter, G. P. Kofinas, C. Folke, N. Abel, W. C. Clark, P. Olsson, D. M. S. Smith, B. Walker, O. R. Young, F. Berkes, R. Biggs, J. M. Grove, R. L. Naylor, E. Pinkerton, W. Steffen, and F. J. Swanson. 2010. "Ecosystem Stewardship: Sustainability Strategies for a Rapidly Changing Planet." Trends in Ecology and Evolution 25 (4): 241-49.

Cumming, G. S., A. Buerkert, E. M. Hoffmann, E. Schlecht, S. von Cramon-Taubadel, and T. Tscharntke. 2014. "Implications of Agricultural Transitions and Urbanization for Ecosystem Services.” Nature 515:50-57.

de Bello, F., S. Lavorel, P. Gerhold, Ü. Reier, and M. Pärtel. 2010. "A Biodiversity Monitoring Framework for Practical Conservation of Grasslands and Shrublands." Biological Conservation 143(1):9-17.

Debussche, M., J. Lepart, and A. Dervieux. 1999. "Mediterranean Landscape Changes: Evidence from Old Postcards." Global Ecology and Biogeography 8(1):3-15.

de Chazal, J. and M. D. A. Rounsevell. 2009. "Land-Use and Climate Change within Assessments of Biodiversity Change: A Review." Global Environmental Change 19(2):306-15.

Diaz, S., S. Lavorel, S. McIntyre, V. Falczuk, F. Casanovess, D. G. Milchunas, C. Skarpe, G. Rusch, M. Sternberg, I. Noy-Meir, J. Landsberg, W. E. I. Zhang, H. Clark, and B. D. Campbell. 2006. "Plant Trait Response to Grazing-A Global Synthesis." Global Change Biology 12:1-29.

Dramstad, W. E., W. J. Fjellstad, G. H. Strand, H. F. Mathiesen, G. Engan, and J. N. Stokland. 2002. "Development and Implementation of the Norwegian Monitoring Programme for Agricultural Landscapes." Journal of Environmental Management 64(1): 49-63.

Duprè, C., C. J. Stevens, T. Ranke, A. Bleeker, C. Peppler-Lisbach, D. J. Gowing, N. B. Dise, E. Dorland, R. Bobbink, and M. Diekmann. 2010. "Changes in Species Richness and Composition in European Acidic Grasslands over the Past 70 Years: The Contribution of Cumulative Atmospheric Nitrogen Deposition." Global Change Biology 16(1): 344-57.

EC (Council Regulation). 2006. Rural Development 2007-2013 Handbook on Common Monitoring and Evaluation Framework; Guidance Document. Brussels, Belgium: Directorate General for Agriculture and Rural Development.

EEA (European Environment Agency). 2010. EU 2010 Biodiversity Baseline. Copenhagen, Denmark: European Environment Agency.

Fédoroff, É., J.-F. Ponge, F. Dubs, F. Fernández-González, and P. Lavelle. 2005. "SmallScale Response of Plant Species to Land-Use Intensification." Agriculture, Ecosystems and Environment 105(1-2):283-90.

Firbank, L. G., S. Petit, S. Smart, A. Blain, and R. J. Fuller. 2008. "Assessing the Impacts of Agricultural Intensification on Biodiversity: A British Perspective.” Philosophical Transactions of the Royal Society B: Biological Sciences 363(1492):777-87.

Fischer, M. and S. Wipf. 2002. "Effect of Low-Intensity Grazing on the Species-Rich Vegetation of Traditionally Mown Subalpine Meadows." Biological Conservation 104(1):1-11.

Flinn, K., M. Vellend, and P. L. Marks. 2005. "Environmental Causes and Consequences of Forest Clearance and Agricultural Abandonment in Central New York, USA." Journal of Biogeography 32:439-52.

García-Ruiz, J. M. and N. Lana-Renault. 2011. "Hydrological and Erosive Consequences of Farmland Abandonment in Europe, with Special Reference to the Mediterranean Region-A Review." Agriculture, Ecosystems and Environment 140(3):317-38.

García-Ruiz, J. M., J. L. López-Moreno, S. M. Vicente-Serrano, T. Lasanta-Martínez, and S. Beguería. 2011. "Mediterranean Water Resources in a Global Change Scenario." Earth-Science Reviews 105:121-39.

Gonçalves, J., R. Henriques, Paulo Alves, R. Sousa-Silva, A. T. Monteiro, Angela Lomba, B. Marcos, and João Honrado. 2016. "Evaluating an Unmanned Aerial Vehicle-Based Approach for Assessing Habitat Extent and Condition in Fine-Scale Early Successional Mountain Mosaics.” Applied Vegetation Science 19(1):132-46. 
Grime, J. P., J. G. Hodgson, and R. Hunt. 1988. Comparative Plant Ecology: A Functional Approach to Common British Species. London, England: Unwin Hyman.

Halada, L., D. Evans, C. Romão, and J.-E. Petersen. 2011. "Which Habitats of European Importance Depend on Agricultural Practices?" Biodiversity and Conservation 20(11): 2365-78.

Halstead, P. 2014. Two Oxen Ahead. John Chichester, England: Wiley \& Sons, Ltd.

Henle, K., D. Alard, J. Clitherow, P. Cobb, L. Firbank, T. Kull, D. McCracken, R. F. A. Moritz, J. Niemela, M. Rebane, D. Wascher, A. Watt, and J. Young. 2008. "Identifying and Managing the Conflicts between Agriculture and Biodiversity Conservation in Europe-a Review." Agriculture, Ecosystems and Environment 124:60-71.

Hobbs, N. T. 2006. "Large Herbivores as Sources of Disturbance in Eco-systems." Pp. 26188 in Large Herbivore Ecology and Ecosystem Dynamics, edited by K. Danell, J. Pastor, R. Bergström, and P. Duncan. Cambridge, England: Cambridge University Press.

Honrado, João Pradinho, J. Alonso, Angela Lomba, J. Gonçalves, A. T. Pinto, S. C. Ribeiro, C. Guerra, R. Almeida, and H. N. Alves. 2011. "Ecologia, diversidade e dinâmicas recentes dos ecossistemas florestais nas paisagens do Norte de Portugal." Pp 118-68. in Florestas do norte de Portugal: História, ecologia e desafios de gestão, edited by J. P. Tereso, J. P. Honrado, A. T. Pinto, and F. C. Rego. Porto, Portugal: InBIO.

IEEP (Institute for European Environmental Policy).. 2007. Guidance Document to the Member States on the Application of the High Nature Value Indicator. Final report for DG Agriculture. Contract Notice 2006-G4-04. pp. 48.

Isselstein, J., B. Jeangros, and V. Pavlu. 2005. "Agronomic Aspects of Biodiversity Targeted Management of Temperate Grasslands in Europe-A Review." Agronomy Research 3: $139-51$.

Jackson, L. E., U. Pascual, and T. Hodgkin. 2007. "Utilizing and Conserving Agrobiodiversity in Agricultural Landscapes." Agriculture, Ecosystems and Environment 121 (3):196-210.

Johnson, P. S., S. R. Shifley, and R. Rogers. 2002. The Ecology and Silviculture of Oaks. New York: CABI Publishing.

Kleijn, D., F. Kohler, A. Báldi, P. Batáry, E. D. Concepción, Y. Clough, M. Díaz, D. Gabriel, A. Holzschuh, E. Knop, A. Kovács, E. J. P. Marshall, T. Tscharntke, and J. Verhulst. 2009. "On the Relationship between Farmland Biodiversity and Land-Use Intensity in Europe." Proceedings of the Royal Society B: Biological Sciences 276:903-9.

Klimek, S., A. R. Kemmermann, M. Hofmann, and J. Isselstein. 2007. "Plant Species Richness and Composition in Managed Grasslands: The relative Importance of Field Management and Environmental Factors." Biological Conservation 134:559-70.

Körner, C. and M. Ohsawa. 2005. "Mountain Systems." Pp. 681-716 in Ecosystems and Human Well-being: Current State and Trends; Findings of the Condition and Trends Working Group, edited by R. M. Hassan, R. Scholes, and N. Ash, vol. 1. Washington, DC: Island Press.

Lasanta, T., J. Arnáez, M. P. Errea, L. Ortigosa, and P. Ruiz-Flaño. 2009. "Mountain Pastures, Environmental Degradation, and Landscape Remediation: The Example of a Mediterranean Policy Initiative." Applied Geography 29(3):308-19.

Lasanta, T., E. Nadal-Romero, and J. Arnáez. 2015. "Managing Abandoned Farmland to Control the Impact of Re-vegetation on the Environment: The State of the Art in Europe." Environmental Science and Policy 52:99-109.

Lasanta, T., E. Nadal-Romero, P. Errea, and J. Arnáez. 2015. "The Effect of Landscape Conservation Measures in Changing Landscape Patterns: A Case Study in Mediterranean Mountains." Land Degradation and Development 27(2):373-86. doi: 10.1002/ ldr.2359.

Launchbaugh, K. and J. Walker. 2006. "Targeted Grazing-A New Paradigm for Livestock Management." Pp 1-8. in Targeted Grazing: A Natural Approach to Vegetation Management and Landscape Enhancement, edited by Karen L. Launchbaugh, John W. Walker, and Ron J. Daines. Englewood, CO: American Sheep Industry Association.

Lloret, F., E. Calvo, X. Pons, and R. Díaz-Delgado. 2002. "Wildfires and Landscape Patterns in the Eastern Iberian Peninsula." Landscape Ecology 17:745-59. 
Loepfe, L., J. Martinez-Vilalta, J. Oliveres, J. Piñol, and F. Lloret. 2010. "Feedbacks between Fuel Reduction and Landscape Homogenisation Determine Fire Regimes in Three Mediterranean Areas." Forest Ecology and Management 259(12):2366-74.

Lomba, Angela, R. G. H. Bunce, R. H. G. Jongman, F. Moreira, and João Honrado. 2010. "Interactions between Abiotic Filters, Landscape Structure and Species Traits as Determinants of Dairy Farmland Plant Diversity." Landscape and Urban Planning 99: 248-58.

Lomba, Angela, J. Gonçalves, F. Moreira, and João Honrado. 2012. "Simulating LongTerm Effects of Abandonment on Plant Diversity in Mediterranean Mountain Farmland." Plant Biosystems—an International Journal Dealing with all Aspects of Plant Biology $147(2): 328-42$.

MacDonald, D., J. R. Crabtree, G. Wiesinger, T. Dax, N. Stamou, P. Fleury, J. Gutierrez Lazpita, and A. Gibon. 2000. "Agricultural Abandonment in Mountain Areas of Europe: Environmental Consequences and Policy Response." Journal of Environmental Management 59:47-69.

Mazoyer, M. and L. Roudart. 2006. A History of World Agriculture: From the Neolithic Age to the Current Crisis. London, England: Earthscan.

Meireles, C., C. Pinto-Gomes, and E. Cano. 2012. "Approach to Climatophilous Vegetation Series of Serra da Estrela (Portugal)." Acta Botanica Gallica 159(3):283-87.

Milchunas, D. G., O. E. Sala, and W. Lauenroth. 1988. "A Generalized Model of the Effects of Grazing by Large Herbivores on Grassland Community Structure." American Naturalist 132(1):87-106.

Millennium Ecosystem Assessment. 2005. Ecosystems and Human Well-being: Biodiversity Synthesis. Washington, DC: World Resources Institute.

Moreira, F., M. J. Pinto, I. Henriques, and T. Marques. 2005. "The Importance of LowIntensity Farming Systems for Fauna, Flora and Habitats Protected under the European 'Birds' and 'Habitats' Directives: Is Agriculture Essential for Preserving Biodiversity in the Mediterranean Region?” Pp. 117-45 in Trends in Biodiversity Research, edited by S. D. Antonello. New York: Nova Science.

Navarro, L. M. and H. M. Pereira. 2012. "Rewilding Abandoned Landscapes in Europe." Ecosystems 15:900-12.

Ostrom, E., J. Burger, C. Field, R. Norgaard, and D. Policansky. 1999. "Revisiting the Commons: Local Lessons, Global Challenges." Science 284:278-82.

Pärtel, M., H. H. Bruun, and M. Sammul. 2005. "Biodiversity in Temperate European Grasslands: Origin and Conservation.” Pp. 1-14 in Integrating Efficient Grassland Farming and Biodiversity: Proceedings of the 13th International Occasional Symposium of the European Grassland Federation, edited by R. Lillak, R. Viiralt, A. Linke, and V. Geherman. Tartu, Estonia. vol. 10.

Peeters, A. and F. Janssens. 1998. "Species-Rich Grasslands: Diagnostics, Restoration and Use in Intensive Livestock Production Systems." Pp. 375-93 in Proceedings of the 17th General Meeting of the European Grassland Federation, Debrecen Agricultural University, Debrecen, Hungary, 18-21 May 1998:, edited by G. Nago and K. Peto.

Pinto-Correia, T. and W. Vos. 2004. "Multifunctionality in Mediterranean LandscapesPast and Future." New Dimensions of the European Landscape 4:135-64.

Plieninger, T. 2006. "Habitat Loss, Fragmentation, and Alteration-Quantifying the Impact of Land-Use Changes on a Spanish Dehesa Landscape by Use of Aerial Photography and GIS." Landscape Ecology 21 (1):91-105.

Plieninger, T. and C. Bieling. 2013. "Resilience-Based Perspectives to Guiding HighNature-Value Farmland through Socioeconomic Change." Ecology and Society 18(4): 20. doi:10.5751/ES-05877-180420.

Poláková, J., G. Tucker, K. Hart, J. Dwyer, and M. Rayment. 2011. Addressing Biodiversity and Habitat Preservation through Measures Applied under the Common Agricultural Policy. London: Institute for European Environmental Policy. 
Prats, S., M. Malvar, M. A. S. Martins, and J. J. Keizer. 2014. "Post-fire Soil Erosion Mitigation: A Review of the Last Research and Techniques Developed in Portugal." Cuadernos de Investigación Geográfica 40:403-27.

Pykälä, J., M. Luoto, R. K. Heikkinen, and T. Kontula. 2005. "Plant Species Richness and Persistence of Rare Plants in Abandoned Semi-natural Grasslands in Northern Europe." Basic and Applied Ecology 6(1):25-33.

Queiroz, C., R. Beilin, C. Folke, and R. Lindborg. 2014. "Farmland Abandonment: Threat or Opportunity for Biodiversity Conservation? A Global Review." Frontiers in Ecology and the Environment 12:288-96.

Robinson, R. A. and W. J. Sutherland. 2002. "Post-war Changes in Arable Farming and Biodiversity in Great Britain." Journal of Applied Ecology 39(1):157-76.

Rook, A. J., B. Dumont, J. Isselstein, K. Osoro, M. F. Wallis DeVries, G. Parente, and J. Mills. 2004. "Matching Type of Livestock to Desired Biodiversity Outcomes in Pastures-A Review." Biological Conservation 119(2):137-50.

Santos, J. M. and Carlos Aguiar. 1995. "Private Hay Meadows and Common Pastures: Integrated Management of Two Ecosystems." Pp 491-501. in Environmental and Land Use Issues: An Economic Prespective, edited by L. Albisu and C. Romero. Kiel, Germany: Wissenschaftsverlag Vauk.

Silva, J. P., J. Toland, W. Jones, J. Eldridge, E. Thorpe, and E. O'Hara. 2008. LIFE and Europe's Grasslands: Restoring a Forgotten Habitat. Luxembourg, edited by B. Redecker, W. Härdtle, P. Finck, U. Riecken, and E. Schröder. Luxembourg: European Communities.

Silva-Pando, F. J., M. P. González-Hernández, and P. Castro Garcia. 1999. "Nutritional Characteristics of Some Common Woody Plants in Shrublands of Galicia (Northwest Iberian Peninsula)." Grassland and Science in Europe 4:121-25.

Silva-Pando, F. J., M. J. R. Lorenzo, and M. P. G. Hernández 2002. "Grasslands and Scrublands in the Northwest of the Iberian Peninsula: Silvopastoral Systems and Nature Conservation." Pp. 271-83 in PastureLandscapes and Nature Conservation, edited by B. Redecker, W. Härdtle, P. Finck, U. Riecken, and E. Schröder. Berlin, Germany: Springer.

Stoate, C., A. Báldi, P. Beja, N. D. Boatman, I. Herzon, A. van Doorn, G. R. de Snoo, L. Rakosy, and C. Ramwell. 2009. "Ecological Impacts of Early 21st Century Agricultural Change in Europe-A Review." Journal of Environmental Management 91 (1):22-46.

Tilman, D., J. Fargione, B. Wolff, C. D'Antonio, A. Dobson, R. Howarth, D. Schindler, W. H. Schlesinger, D. Simberloff, and D. Swackhamer. 2001. "Forecasting Agriculturally Driven Global Environmental Change." Science 292(5515):281-84.

Tscharntke, T., A. M. Klein, A. Kruess, I. Steffan-Dewenter, and C. Thies. 2005. "Landscape Perspectives on Agricultural Intensification and Biodiversity-Ecosystem Service Management." Ecology Letters 8(8):857-74.

Vassilev, K., H. Pedashenko, S. C. Nikolov, I. Apostolova, and J. Dengler. 2011. "Effect of Land Abandonment on the Vegetation of Upland Semi-natural Grasslands in the Western Balkan Mts., Bulgaria." Plant Biosystems—an International Journal Dealing with All Aspects of Plant Biology 145(3):654-65.

Vera, F. W. M. 2000. Grazing Ecology and Forest History. Wallingford, England: CABI. 